\title{
Purchasing Pattern Of Processed Foods And Awareness About Food Labelling Among Working And Non-Working Women
}

\author{
Mrs. Mayura Kathane ${ }^{1}$ and Dr. Rekha Sharma ${ }^{2}$ \\ 1 (Research Scholar Post Graduate Teaching Department of Home Science) \\ 2(Associate Professor, UGC-Human Resource Development Centre, Rashtrasant Tukadoji Maharaj Nagpur \\ University, Nagpur, Maharashtra, India)
}

\begin{abstract}
Food consumption pattern in India is rapidly changing from unprocessed, unbranded low quality food products to the processed, packaged products. About 200 working and 200 non-working women were selected by convenience sampling method from Nagpur City, Maharashtra, India. The data on purchasing of processed food and reading food labels was collected using interview cum questionnaire method. The results of the study showed that the average age of working women was $39.39+6.15$ years and non-working women was $38.36+5.7$ years. The average monthly income of working and non-working women was Rs. $38,12+19,55$ and Rs. 40,62 + 20,82 respectively. There are multiple factors that affect the consumers' behaviour towards the purchasing of processed foods. Children $(21.4 \%)$ were the major users in working women category whereas all the family members $(26.7 \%)$ were the major consumers of processed food from non-working women category. TV/Radio/Internet (media) were the main source of information that affect purchasing of processed food in both working $(37.6 \%)$ and non-working $(37.8 \%)$ women category. Overall quality was the main factor considered by both working $(36 \%)$ and non-working $(40.9 \%)$ women while purchasing processed food. The highest consumption of processed food was found to be for special occasions in both working (21.9\%) and non-working (20.4\%) women. The majority of non-working $(29.5 \%)$ women preferred to buy the processed food from super store whereas majority of working women (27.3\%) preferred to buy processed food from local kirana shop. Most of the respondents read food labels before purchasing processed food in both working $(49.6 \%)$ and nonworking $(49.6 \%)$ women. Health reasons were the major motivating factor for both working $(28.3 \%)$ and nonworking $(29.8 \%)$ women. The major reason for not reading food labels was the trust of the buyers on the brand/outlet for both working (22.7\%) and non-working (25\%) women. Expiry date was the most read component of the food label for both working $(43.5 \%)$ and non-working $(43.2 \%)$ women. The small fonts (and hence difficulty in reading) was the major difficulty faced by both working $(22.2 \%)$ and non-working $(24.2 \%)$ women in reading the labels.
\end{abstract}

Keywords-Non-working Women, Labelling, Processed food, Purchasing, Working Women,

\section{INTRODUCTION}

Today's consumer is becoming more and more demanding about what he is consuming, what quality of food he is getting and how safe it is for his and his family's consumption(Food and Agriculture Organization of the United Nations). Consumers have a right to expect that the foods they purchase and consume will be safe and of high quality. Increasing urbanization, dynamic lifestyle changes and increasing number of working women andnuclear families are changing the global setting for the food industry. Shift in economic power and demographics are expected to change consumers' food preferences and lead to the evolution of the global food supply chains. This trend is resulting in greater consumer expectations with regards to safety, quality, integrity and traceability of food across all emerging economies [1). Food consumption pattern in India is rapidly changing from unprocessed, unbranded low quality food products to the processed, packaged products [2].The behavior of consumers on purchasing of branded processed food. Variables considered were brand attributes, brand endorsement, brand equity, ethical concerns and demography. They found that trust and safety are the two vital parameters driving consumers towards brands [3]. Even though there are other parameter influencing consumers but trust and safety creates long-lasting influence on consumer mind. Though several scientists[4-17] have carried out studies on processed foods and food labelling however there are negligible studies carried out in Central India on purchasing pattern and awareness about food labelling particularly with reference to working and non working women. Hence the present study was proposed to be carried out in Nagpur city.

\section{OBJECTIVES}

2.1To study the socio-economic conditions of working and non-working women in Nagpur city.

2.2To assess the purchasing pattern of processed food of working and non-working women of Nagpur city. 
2.3To study the awareness of food labelling among working and non-working women of Nagpur city.

\section{METHODOLOGY}

The present study was conducted in Nagpur City, Maharashtra, India. About 200 working and nonworking women each were selected by judgmental sampling method. The working women were selected from schools, colleges, hospitals and different institutions. The non-working women were selected from kitty parties, temples, gardens etc. The questionnaire cum interview method was used to elicit information. A structured questionnaire was developed to assess the socio-economic conditions, purchasing pattern of processed food products and awareness of food labelling. The data was collected by personal questionnaire method. Data was tabulated and was analyzed statistically using SPSS version 17. Mean, Standard Deviation and Chi square test were computed and the Confidence Interval was $95 \%$.

\section{RESULTS AND DISCUSSION}

The results of the study are discussed below.

\subsection{Demographic profile}

The demographic profiles of working and non-working women under study are discussed below.

Table 4.1

Demographic Profile of working and nonworking women

\begin{tabular}{|c|c|c|c|c|}
\hline \multirow{2}{*}{$\begin{array}{l}\text { Demographic } \\
\text { Parameters } \\
\end{array}$} & \multirow[t]{2}{*}{ Category } & \multicolumn{3}{|c|}{ Number of Consumers } \\
\hline & & $\begin{array}{l}\text { Working } \\
\mathrm{N}=200\end{array}$ & $\begin{array}{l}\text { Non-working } \\
\mathbf{N}=\mathbf{2 0 0}\end{array}$ & Total \\
\hline \multirow[t]{4}{*}{ Age(Years) } & $30-35$ & $63(31.5)$ & $71(35.5)$ & 134 \\
\hline & $36-40$ & $59(29.5)$ & $70(35.0)$ & 129 \\
\hline & $41-45$ & $39(19.5)$ & $30(15.0)$ & 69 \\
\hline & $46-50$ & $39(19.5)$ & $29(14.5)$ & 68 \\
\hline Mean Age $M \pm S D$ & \multicolumn{2}{|c|}{$39.39 \pm 6.1$} & \multicolumn{2}{|l|}{$38.36 \pm 5.7$} \\
\hline \multirow[t]{5}{*}{ Qualification } & Undergraduate & $14(7.0)$ & $5(2.5)$ & 19 \\
\hline & Graduate & $28(14.0)$ & $68(34.0)$ & 96 \\
\hline & Graduate+ & $54(27.0)$ & $33(16.5)$ & 87 \\
\hline & Post Graduate & $38(19.0)$ & $69(34.5)$ & 107 \\
\hline & Post Graduate+ & $66(33.0)$ & $25(12.5)$ & 91 \\
\hline \multirow[t]{2}{*}{ Family Type } & Nuclear & $99(49.5)$ & $84(42.0)$ & 183 \\
\hline & Joint & $101(50.5)$ & $116(58.0)$ & 217 \\
\hline \multirow[t]{3}{*}{ Family Size } & $1-4$ members & $130(65.0)$ & $105(52.5)$ & 235 \\
\hline & $5-10$ members & $69(34.5)$ & $91(45.5)$ & 160 \\
\hline & Above 10 members & $1(0.5)$ & $4(2.0)$ & 5 \\
\hline \multirow[t]{3}{*}{ Earning Members } & 1 member & $17(8.5)$ & $117(58.5)$ & 134 \\
\hline & 2 member & $146(73.0)$ & $47(23.5)$ & 193 \\
\hline & above2 members & $37(18.5)$ & $36(18.0)$ & 73 \\
\hline \multirow[t]{3}{*}{ Monthly Income(Rs) } & Up to 25,000 & $57(28.5)$ & $43(21.5)$ & 100 \\
\hline & $25,000-50,000$ & $77(38.5)$ & $71(35.5)$ & 148 \\
\hline & Above 50,000 & $66(33.0)$ & $86(43.0)$ & 152 \\
\hline$M \pm S D$ & \multicolumn{2}{|c|}{$38,125 \pm 19,550$} & \multicolumn{2}{|l|}{$40,625+20,825$} \\
\hline \multirow{3}{*}{$\begin{array}{l}\text { Monthly Income Spent on } \\
\text { food (Rs) }\end{array}$} & Up to 10,000 & $162(81.0)$ & $164(82.0)$ & 326 \\
\hline & 11000 to 20000 & $35(17.5)$ & $34(17.0)$ & 69 \\
\hline & Above 20000 & $3(1.5)$ & $2(1.0)$ & 5 \\
\hline$M \pm S D$ & \multicolumn{2}{|c|}{$8465.5 \pm 5181.08$} & \multicolumn{2}{|l|}{$8625 \pm 4716.25$} \\
\hline \multirow{3}{*}{$\begin{array}{l}\text { Monthly Income Spent on } \\
\text { Processed Foods (Rs) }\end{array}$} & Up to 10000 & 149(74.5) & 159(79.5) & 308 \\
\hline & 11000 to 20000 & $37(18.5)$ & $28(14.0)$ & 65 \\
\hline & Above 20000 & $14(7.0)$ & $13(6.5)$ & 27 \\
\hline$M \pm S D$ & \multicolumn{2}{|c|}{$1093.5 \pm 1126.94$} & \multicolumn{2}{|l|}{$1029 \pm 972.60$} \\
\hline
\end{tabular}

(Numbers in parenthesis indicates percent cases.)

Table 4.1 shows distribution of working and non-working women according to their demographic profile. The average age of working women was $39.39 \pm 6.15$ years and that of non-working women was $38.36 \pm 5.7$ years. The majority of working women $(33 \%)$ were post graduate with additional qualifications whereas majority 
non-working women were either only graduate $(34 \%)$ or post-graduate $(34.5 \%)$. The working women were significantly $\left(\chi^{2}=53.45, \mathrm{p}=.000\right)$ more qualified than that of non-working women. About $50.5 \%$ working and $58 \%$ non-working women were from joint families. Also, majority of both working $(65 \%)$ and non-working $(52.5 \%)$ women had 1 to 4 members in their families and a significant association $\left(\chi^{2}=7.48, p=.024\right)$ was also observed between the working status of women and family size. The number of earning members were significantly more $\left(\chi^{2}=12.42, \mathrm{p}=000\right)$ in working women's family $(73 \%)$ as compared to non-working $(58.5 \%)$ women. The average monthly income of working women was Rs. 38,125+19,550 and non-working women were Rs. 40,625+20,825. The average income spent on food by working women was Rs. 8465.5 \pm 5181.08 and non-working women was Rs.8625 \pm 4716.25 . The average monthly income spent on processed food for working and non-working women was Rs $1093.5 \pm 1126.94$ and Rs 1029+972.60 respectively.

\section{PURCHASING OF PROCESSED FOODS}

In the present investigation, an attempt was made to find out the factors that affect purchasing of processed food viz., users of processed foods in the family, source of information about processed foods, issues while purchasing processed food, frequency of consumption of processed food and places of purchase. The results of the study are presented below.

\subsection{Users of Processed food}

Consumer, irrespective of income groups, is mainly influenced by the opinions of their family members[4].The distribution of users of processed food in the family surveyed in present investigation is presented in Table 4.2.1 and Figure 4.2.1.

Table 4.2.1:

Distribution of working and non-working women according to users of processed food

\begin{tabular}{|l|l|l|l|l|}
\hline SN & Users of Processed Foods & Working & Non-Working & Total \\
\hline $\mathbf{1}$ & Children & $84(21.4)$ & $72(18.3)$ & $156(39.7)$ \\
\hline $\mathbf{2}$ & College Going & $16(4.1)$ & $16(4.1)$ & $32(8.1)$ \\
\hline $\mathbf{3}$ & Adults & $22(5.6)$ & $10(2.5)$ & $32(8.1)$ \\
\hline $\mathbf{4}$ & All the Family Members & $83(21.1)$ & $105(26.7)$ & $188(47.8)$ \\
\hline & Total & $196(49.9)$ & $197(50.1)$ & $393(100)$ \\
\hline
\end{tabular}

(Numbers in parenthesis indicates per cent cases.)

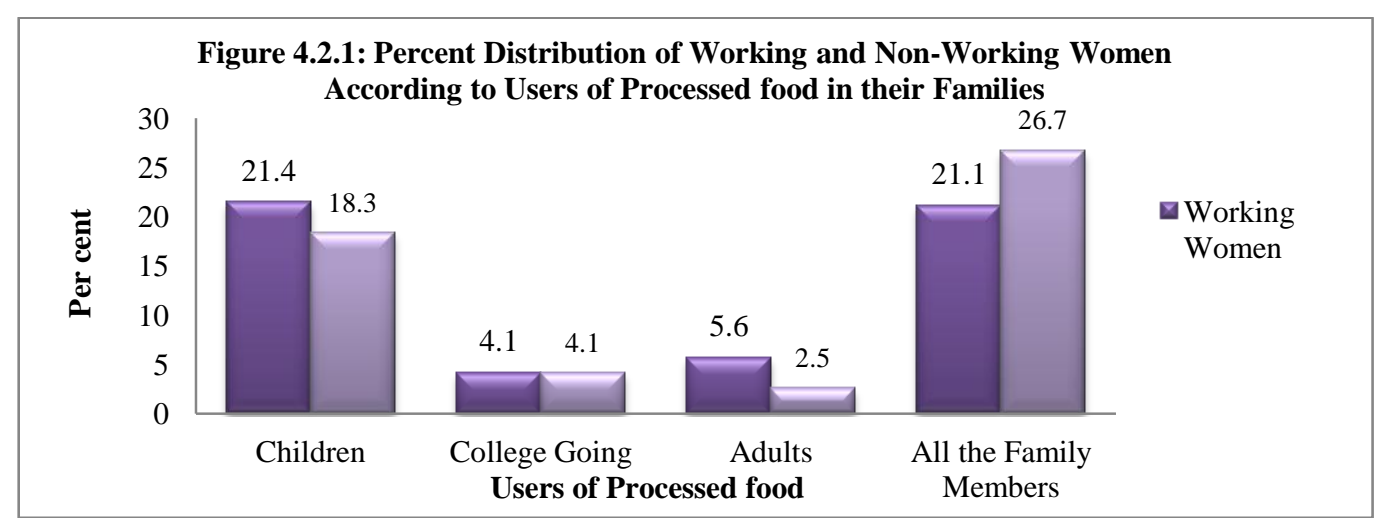

Table 4.2.1 and Figure 4.2.1 reveals that 'all the family members' (26.7\%) were the major consumers of processed food from non-working women category whereas children $(21.4 \%)$ were the major users in working women category. Children were the next important users of processed food. For both working and non-working women families, the college-going and adults were only minor users of processed food.

\subsubsection{Source of Information or processed Foods}

The source of information for purchasing of processed food in the family has been presented in Table 4.2.2 and Figure 4.2.2.

Table 4.2.2:Distribution of working and non-working women according to source of information

\begin{tabular}{|l|l|l|l|l|}
\hline $\mathbf{S N}$ & Sources of Information & Working & Non-Working & Total \\
\hline $\mathbf{1}$ & Shopkeeper & $34(8.5)$ & $35(8.8)$ & $69(17.3)$ \\
\hline $\mathbf{2}$ & TV/Radio/Internet & $150(37.6)$ & $151(37.8)$ & $301(75.4)$ \\
\hline $\mathbf{3}$ & Friends \& Relatives & $46(11.5)$ & $60(15)$ & $106(26.6)$ \\
\hline $\mathbf{4}$ & Newspapers \& Magazines & $26(6.5)$ & $33(8.3)$ & $59(14.8)$ \\
\hline $\mathbf{5}$ & Others & $4(1)$ & $5(1.3)$ & $9(2.3)$ \\
\hline & Total & $200(50.1)$ & $199(49.9)$ & $399(100)$ \\
\hline
\end{tabular}

(Numbers in parenthesis indicates per cent cases.) 


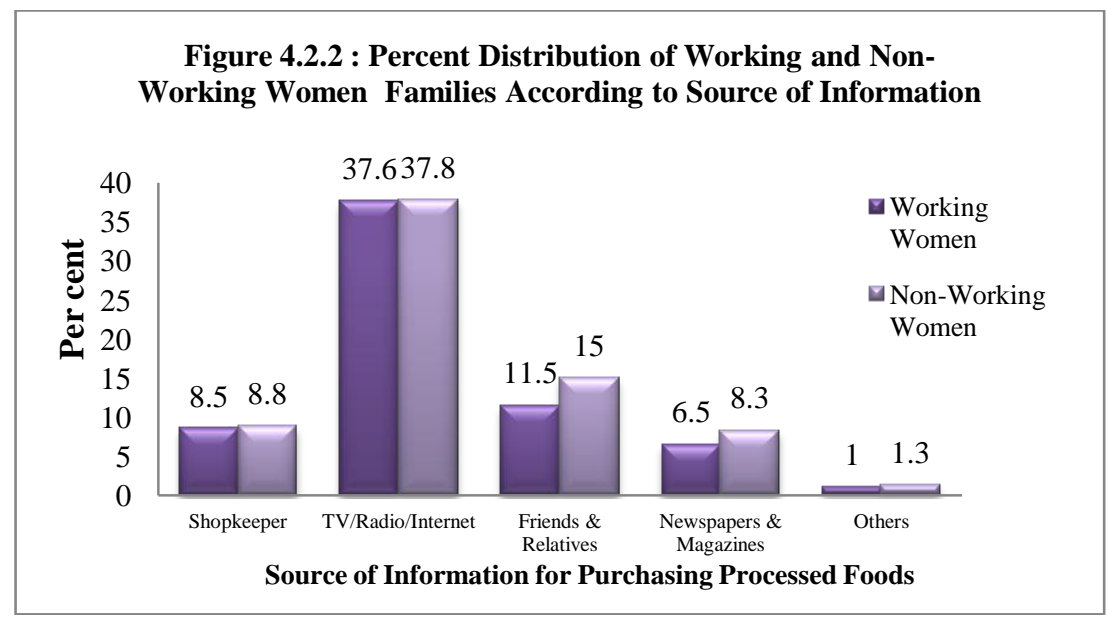

Table 4.2.2 and Figure 4.2.2illustratesthat TV/Radio/Internet (media)were the main source of information for purchase of processed food in both working (37.6\%) and non-working (37.8\%) women category. It shows that the reach of new technologies in spreading information/awareness surpasses any other source and is fairly same in working and non-working categories. While evaluating the impact of advertising on consumer durables market observed that 'friends' is the main influence followed by relatives and hence they should be given more emphasis while planning promotion strategies. Advertisement is the next major influencing factor for the consumer durables [5].

Most of the families take purchase decisions collectively in the case of consumer durables and also revealed that advertisement or publicity through mass media proves to be the best source of reaching the public closely followed by information from friends and relatives[6]. The rural consumers give more importance to the advertisements compared to urban consumers. Both rural and urban groups found that all the advertising media are equally important and effective [7].

\subsubsection{Factors Affecting Purchasing of Processed Food}

The quality of the product and its easy availability are the primary and the vital determinants of any consumer's buying behaviour [8].The issues while purchasing processed food has been presented in Table 4.2.3 and Figure 4.2.3.

Table 4.2.3:

Distribution of working and non-working women according to factors affecting purchasing of processed food

\begin{tabular}{|l|l|l|l|l|}
\hline SN & Issues while purchasing PF & Working & Non-working & Total \\
\hline $\mathbf{1}$ & Price & $39(9.9)$ & $28(7.1)$ & $67(17)$ \\
\hline $\mathbf{2}$ & Overall Quality & $142(36)$ & $161(40.9)$ & $303(76.9)$ \\
\hline $\mathbf{3}$ & Convenience & $17(4.3)$ & $16(4.1)$ & $33(8.4)$ \\
\hline $\mathbf{4}$ & Brand Image & $42(10.7)$ & $35(8.9)$ & $77(19.5)$ \\
\hline $\mathbf{5}$ & Any other & $10(2.5)$ & $8(2)$ & $18(4.6)$ \\
\hline & Total & $197(50)$ & $197(50)$ & $394(100)$ \\
\hline
\end{tabular}

(Numbers in parenthesis indicates per cent cases.)

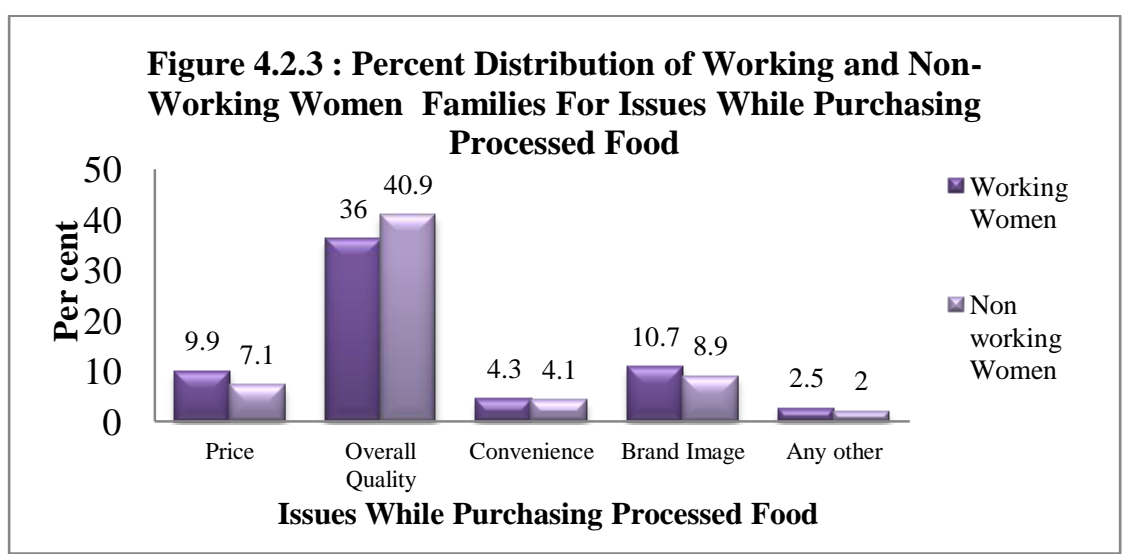


Table 4.2.3 and Figure 4.2.3 shows the issues while purchasing processed food. Overall quality of food was the main factor considered by both working (36\%) and non-working (40.9\%) women while purchasing processed food. Brand image was the next important issue while purchasing processed food for both working $(10.7 \%)$ and non-working (8.9) women and was closely followed by price (working 9.9, non-working 7.1\%) and convenience (working 4.3, non-working 4.1\%). The religious and health issues were reasons under any other options for purchasing processed food. A well designed packaging acts as the main identifying feature for quality and quantity and make the consumers more informative and choosy. It further informs the consumers as to what quality, quantity and price, the package is worth off [9]. The majorities of consumers were highly enlightened and are concerned of quality of the products [10].

\subsubsection{Frequency of Consumption of Processed Food} Figure 4.2.4.

The frequency of consumption of processed food in the family has been presented in Table 4.2.4 and

Table 4.2.4

Distribution of working and non- working women according to frequency of consumption of processed food

\begin{tabular}{|l|l|l|l|l|}
\hline SN & Frequency of consumption & Working & Non-working & Total \\
\hline $\mathbf{1}$ & Weekdays & $11(2.9)$ & $13(3.4)$ & $24(6.3)$ \\
\hline $\mathbf{2}$ & Weekends & $42(11)$ & $55(14.4)$ & $97(25.3)$ \\
\hline $\mathbf{3}$ & Special Occasion & $84(21.9)$ & $78(20.4)$ & $162(42.3)$ \\
\hline $\mathbf{4}$ & Festivals & $17(4.4)$ & $22(5.7)$ & $39(10.2)$ \\
\hline $\mathbf{5}$ & Children's vacation & $42(11)$ & $36(9.4)$ & $78(20.4)$ \\
\hline $\mathbf{6}$ & Throughout the year & $25(6.5)$ & $27(7)$ & $52(13.6)$ \\
\hline & Total & $187(48.8)$ & $196(51.2)$ & $383(100)$ \\
\hline
\end{tabular}

(Numbers in parenthesis indicates per cent cases.)

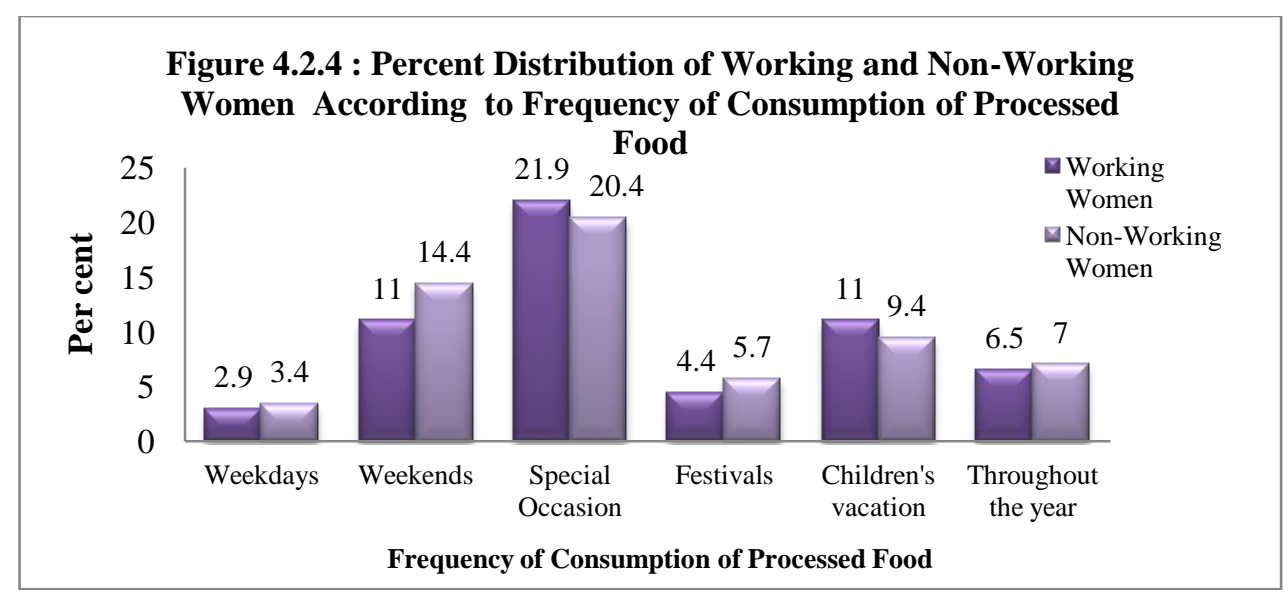

Table 4.2.4 and Figure 4.2.4 illustrates the frequency of consumption of processed food for working and nonworking women category. The highest consumption of processed food was found to be for special occasions in both working $(21.9 \%)$ and non-working $(20.4 \%)$ women. The consumption of processed food at the time of festivals was found to be much lower as compared to at weekends and in children's vacation. This signifies that home-made traditional food is still preferred at the time of Festivals than readymade processed food.

\subsubsection{Places of Purchase for Processed Food}

The places from where the purchase for processed food in the family has been presented in Table 4.2.5 and Figure 4.2.5.

Table 4.2.5

Distribution of working and non-working women according to places of purchase for processed food

\begin{tabular}{|l|l|l|l|l|}
\hline SN & $\begin{array}{l}\text { Places of Purchased for } \\
\text { Processed Food }\end{array}$ & Working & Non-working & Total \\
\hline $\mathbf{1}$ & Local kirana shop & $108(27.3)$ & $85(21.5)$ & $193(48.7)$ \\
\hline $\mathbf{2}$ & Super Store & $88(22.2)$ & $117(29.5)$ & $205(51.8)$ \\
\hline $\mathbf{3}$ & Mall & $17(4.3)$ & $31(7.8)$ & $48(12.1)$ \\
\hline $\mathbf{4}$ & Order Online & $5(1.3)$ & $8(2)$ & $13(3.3)$ \\
\hline & Total & $197(49.7)$ & $199(50.3)$ & $396(100)$ \\
\hline
\end{tabular}

(Numbers in parenthesis indicates per cent cases.) 


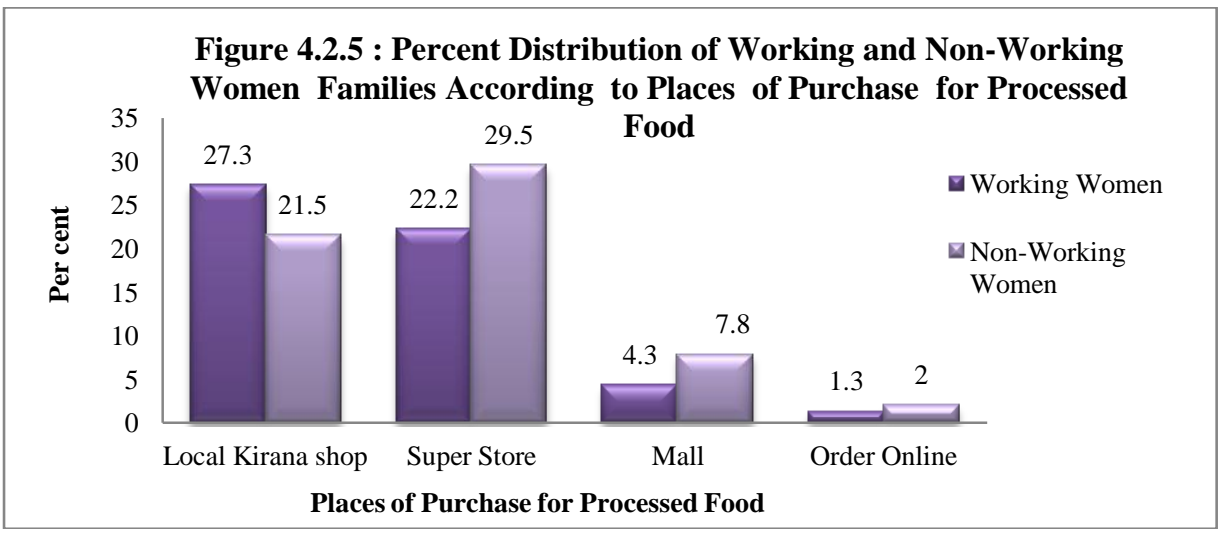

It is revealed from the Table 4.2.5 and Figure 4.2.5 that the majority of non-working $(29.5 \%)$ women preferred to buy the processed food from super store whereas majority of working women(27.3\%) preferred to buy processed food from local kirana shop. Online shopping for processed food was still found to be minimal and it may take time for people to adapt to this method of buying processed food. However, local kirana shop still has a prominent place in the choices for people to buy processed food from as it is more convenient especially for working women. The consumers uniformly, both in urban and rural areas, desire to have quality of the products at reasonable price and tend to rely more on the advice of the retailers [10].

\subsection{Food Labels}

Food labelling is found to be a very important public health tool aimed at providing consumers with information which may influence their purchasing decisions [11]. The aim of food labelling is to provide consumers with information which may influence their purchasing decisions. For example, consumers may want to know what ingredients are in a food product, how to cook it, how it should be stored, and its best-before or use-by date, its fat content or other nutritional properties. Detailed, honest and accurate labelling is essential to inform the consumer as to the exact nature and characteristics of the food product, enabling them to make a more informed choice[12]. In the present investigation, an attempt was made to find out the factors that affect label reading of processed food viz., awareness about label reading, motivating factors to read food labels, reasons for not reading the food labels, most read component of the food label, difficulties in reading label. The results on the above discussed aspects of label reading in processed foods have been presented below.

\subsubsection{Awareness about Label Reading}

Labelling is a very important tool for transferring information on product characteristics to consumers but its potential is not always well exploited [13].Distribution of working and non-workingwomen families according to awareness about label reading while purchasing processed food has been presented in Table 4.3.1 and Figure 4.3.1.

Table 4.3.1

Distribution of working and non-working women according to awareness about label reading

\begin{tabular}{|l|l|l|l|l|}
\hline SN & Awareness about Label Reading & Working & Non-working & Total \\
\hline $\mathbf{1}$ & Yes & $196(49.6)$ & $196(49.6)$ & $392(99.2)$ \\
\hline $\mathbf{2}$ & No & $1(0.3)$ & $3(0.8)$ & $4(1)$ \\
\hline & Total & $197(49.9)$ & $198(50.1)$ & $395(100)$ \\
\hline
\end{tabular}

(Numbers in parenthesis indicates per cent cases.)

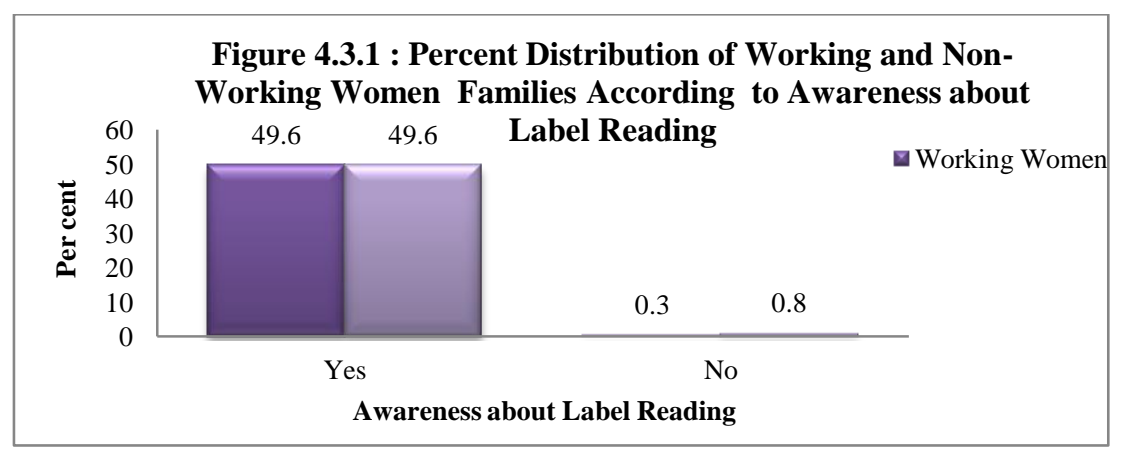

The data from Table 4.3.1 and Figure 4.3.1 shows that most of the respondents do read labels before purchasing processed food in both working (49.6\%) and non-working(49.6\%) women. This shows that today's 
buyer is an informed buyer. Buyer tends to choose the products for which the information is published transparently. This information enables the buyer to make comparisons and arrive at a decision based on his/her requirements.

\subsubsection{Motivating Factor to Read Labels}

Package is one of the main elements of the product appearance and as such is an important source of information since consumers rely heavily on labels for product information and also packaging is a significant marketing expenditure larger than advertising itself[14]. Distribution of working and non-working women families according to motivating factors to read labels while purchasing processed food has been presented in Table 4.3.2 and Figure 4.3.2.

Table 4.3.2

Distribution of working and non-working women according to motivating factor to read labels

\begin{tabular}{|l|l|l|l|l|}
\hline SN & Motivating Factor to Read Labels & Working & Non-working & Total \\
\hline $\mathbf{1}$ & Product Appearance & $27(6.9)$ & $24(6.2)$ & $51(13.1)$ \\
\hline $\mathbf{2}$ & Like to know specific information & $69(17.7)$ & $55(14.1)$ & $124(31.9)$ \\
\hline $\mathbf{3}$ & Preference of some ingredients & $51(13.1)$ & $40(10.3)$ & $91(23.4)$ \\
\hline $\mathbf{4}$ & Health Reasons & $110(28.3)$ & $116(29.8)$ & $226(58.1)$ \\
\hline $\mathbf{5}$ & Religious beliefs & $4(1)$ & $6(1.5)$ & $10(2.6)$ \\
\hline $\mathbf{6}$ & Advertisements or food promotion & $15(3.9)$ & $22(5.7)$ & $37(9.5)$ \\
\hline $\mathbf{7}$ & Any other & $8(2.1)$ & $7(1.8)$ & $15(3.9)$ \\
\hline & Total & $193(49.6)$ & $196(50.4)$ & $389(100)$ \\
\hline
\end{tabular}

(Numbers in parenthesis indicates per cent cases.)

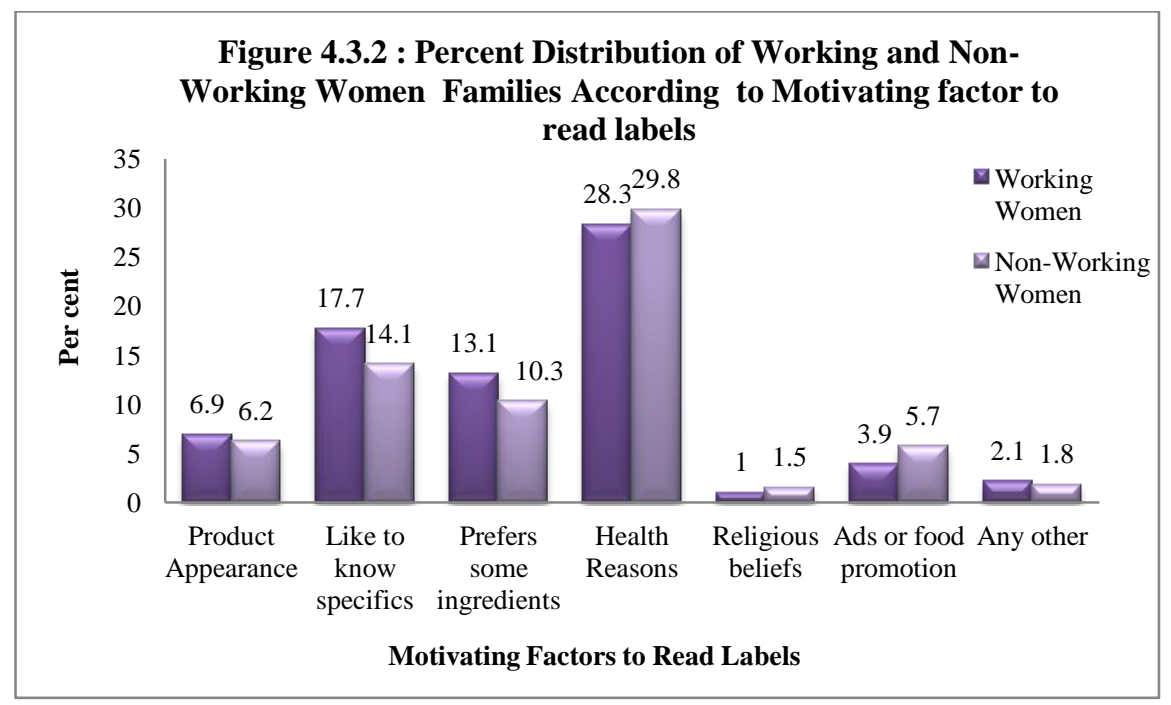

Table 4.3.2 and Figure 4.3.2 specifies the motivating factors to read labels among working and nonworking women while purchasing processed food. Health reasons (Working women 28.3\%, Nonworking $29.8 \%$ ) were found to be the most opted motivating factor followed by like to know specifics (Working women $17.7 \%$, Nonworking $14.1 \%$ ), prefers some ingredients (Working women 13.1\%, Non-working 10.3\%), product appearance (Working women 6.9\%, Nonworking 6.2\% ), advertisement or food promotions (Working women $3.9 \%$, Non-working $5.7 \%$ ). About $1 \%$ working and $1.5 \%$ non working women read labels due to religious believes. Consumers' usage of food label varies enormously depending on their motivation, personal ability and shopping behaviour. Particularly, consumers' usage of label elements depends on how important they value the labelled information [13].

\subsubsection{Reasons for Not Reading Food Labels}

Distribution of working and non-working women families according to reasons for not reading food labels while purchasing processed food has been presented in Table 4.3.3 and Figure 4.3.3.

Table 4.3.3Distribution of working and non-working women according to reasons for not reading the labels

\begin{tabular}{|l|l|l|l|l|}
\hline SN & Reasons For Not Reading The Labels & Working & Non-working & Total \\
\hline $\mathbf{1}$ & Familiarity/trust with the food/outlet & $60(22.7)$ & $66(25)$ & $126(47.7)$ \\
\hline $\mathbf{2}$ & Time constraints & $33(12.5)$ & $38(14.4)$ & $71(26.9)$ \\
\hline $\mathbf{3}$ & Unclear about full label component & $18(6.8)$ & $21(8)$ & $39(14.8)$ \\
\hline $\mathbf{4}$ & Any other & $22(8.3)$ & $19(7.2)$ & $41(15.5)$ \\
\hline & Total & $125(47.3)$ & $139(52.7)$ & $264(100)$ \\
\hline
\end{tabular}

(Numbers in parenthesis indicates per cent cases.) 


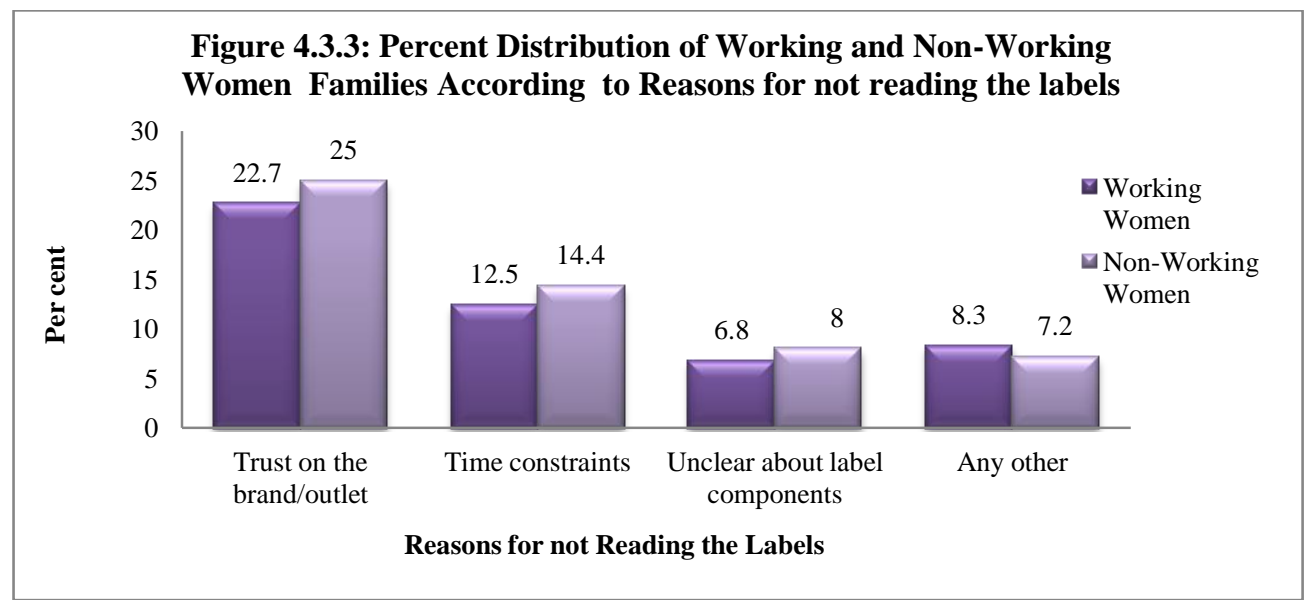

The data from Table 4.3.3 and Figure 4.3.3 shows that the major reason for not reading food labels was the trust of the buyers on the brand/outlet for both working $(22.7 \%)$ and non-working (25\%) women. Lack of time was also found to be another major reason for both working $(12.5 \%)$ and non-working $(14.4 \%)$ women to not read the labels. No interest, not having enough time to read labels or having a prior knowledge about food items were found as reasons for lack of attention to food labels in American subjects [15].

\subsubsection{Most Read Component of the Food Label}

Accurate, easy-to-read, and scientifically valid nutrition and health information on food labels is an essential component of a comprehensive public health strategy to help consumers improve their diets and reduce their risk of diet-related diseases [16].Distribution of working and non-working women families according to the most read component of food label while purchasing processed food has been presented in Table 4.3.4 and Figure 4.3.4.

Table 4.3.4

Distribution of working and non-working women according to most read component of the food label

\begin{tabular}{|l|l|l|l|l|}
\hline SN & Most read component of the food label & Working & Non-working & Total \\
\hline $\mathbf{1}$ & Brand Name & $98(24.6)$ & $112(28.1)$ & $210(52.8)$ \\
\hline $\mathbf{2}$ & Manufacture Date & $134(33.7)$ & $148(37.2)$ & $282(70.9)$ \\
\hline $\mathbf{3}$ & Expiry Date & $173(43.5)$ & $172(43.2)$ & $345(86.7)$ \\
\hline $\mathbf{4}$ & Nutritional Information & $84(21.1)$ & $88(22.1)$ & $172(43.2)$ \\
\hline $\mathbf{5}$ & List of Ingredients & $83(20.9)$ & $78(19.6)$ & $161(40.5)$ \\
\hline $\mathbf{6}$ & Net Content & $41(10.3)$ & $57(14.3)$ & $98(24.6)$ \\
\hline $\mathbf{7}$ & Price of food & $92(23.1)$ & $95(23.9)$ & $187(47)$ \\
\hline $\mathbf{8}$ & Health Claims & $47(11.8)$ & $52(13.1)$ & $99(24.9)$ \\
\hline $\mathbf{9}$ & Specific Logo & $47(11.8)$ & $54(13.6)$ & $101(25.4)$ \\
\hline $\mathbf{1 0}$ & Food storage Instructions & $54(13.6)$ & $71(17.8)$ & $125(31.4)$ \\
\hline & Total & $198(49.7)$ & $200(50.3)$ & $398(100)$ \\
\hline
\end{tabular}

(Numbers in parenthesis indicates per cent cases.)

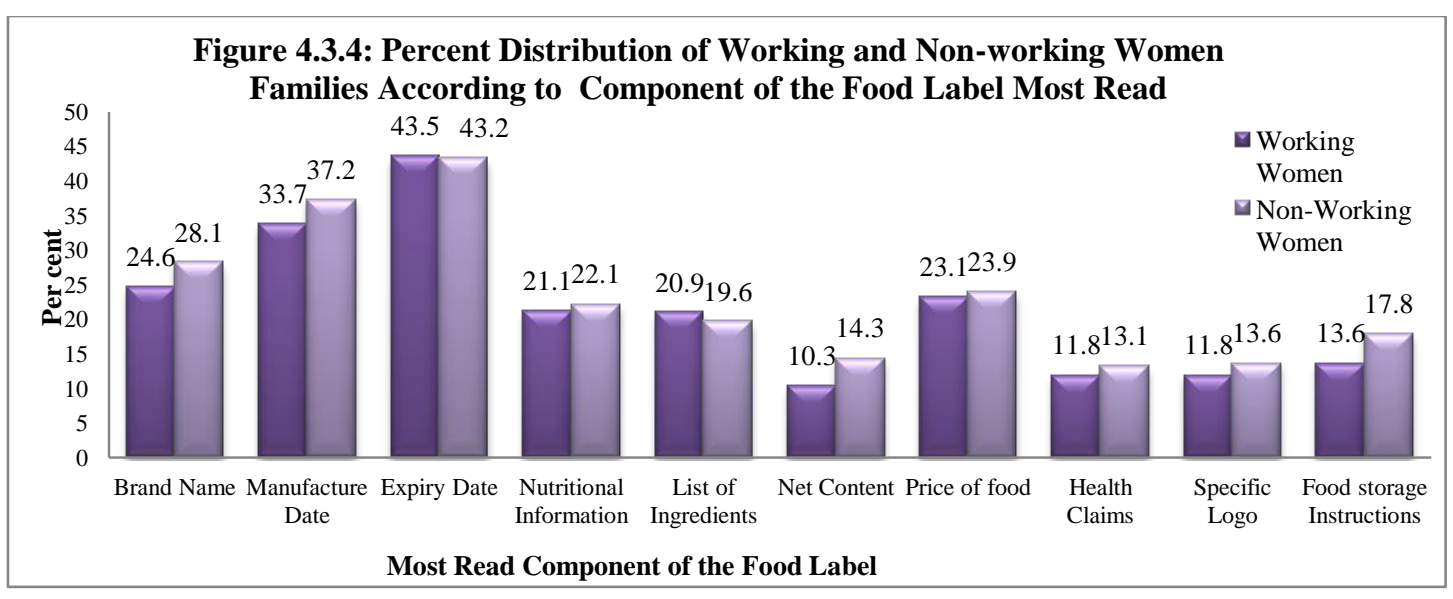


The data presented in Table 4.3.4 and Figure 4.3.4 reveals that expiry date was the most read component of the food label for both working (43.5\%) and non-working (43.2\%) women. The next important label component read was manufacture date for both working $(33.7 \%)$ and non-working (37.2\%) women and was closely followed by brand name (working $24.6 \%$, non-working $28.1 \%$ ) price of food(Working women 23.1\%; Nonworking 23.9\% ) nutritional information (Working women 21.1\%; Nonworking 22.1\% ), list of ingredients (Working women 20.9\%, Non-working 19.6\%), food storage instruction (Working women $13.6 \%$, Nonworking 17.8\%), specific logo (Working women 11.8\%, Non-working $13.6 \%$ ), health claims (Working women 11.8, Nonworking 13.1\%), About $10.3 \%$ working and 14.3\% non-working women check the net content written on the product.

Reading nutrition labels can help the buyer choose between processed food products and keep a check on the amount of processed foods (high in fat, salt and added sugars) included in the diet. Most pre-packed foods have a nutrition label on the back or side of the packaging. This type of label includes information on energy $(\mathrm{kJ} / \mathrm{kcal})$, fat, saturates (saturated fat), carbohydrate, sugars, protein and salt. It may also provide additional information on certain nutrients such as fiber. All nutrition information is provided per 100 grams and sometimes per portion of the food [17].

\subsubsection{Difficulties in Reading Label}

Distribution of working and non-working women families according to difficulties in reading label while purchasing processed food was surveyed in the present investigation and is presented in Table 4.3.5 and Figure 4..3.5.

Table 4.3.5

Distribution of working and non-working women according to difficulties in reading label

\begin{tabular}{|l|l|l|l|l|}
\hline SN & Difficulties in Label Reading & Working & Non-working & Total \\
\hline $\mathbf{1}$ & Unfamiliar Language & $37(10.4)$ & $30(8.4)$ & $67(18.8)$ \\
\hline $\mathbf{2}$ & Use of technical or specific language & $50(14)$ & $34(9.6)$ & $84(23.6)$ \\
\hline $\mathbf{3}$ & Incomplete Information & $48(13.5)$ & $52(14.6)$ & $100(28.1)$ \\
\hline $\mathbf{4}$ & Hidden Information & $63(17.7)$ & $49(13.8)$ & $112(31.5)$ \\
\hline $\mathbf{5}$ & Small Fonts & $79(22.2)$ & $86(24.2)$ & $165(46.3)$ \\
\hline $\mathbf{6}$ & Not aware of Food Labels & $13(3.7)$ & $11(3.1)$ & $24(6.7)$ \\
\hline & Total & $179(50.3)$ & $177(49.7)$ & $356(100)$ \\
\hline
\end{tabular}

(Numbers in parenthesis indicates per cent cases.)

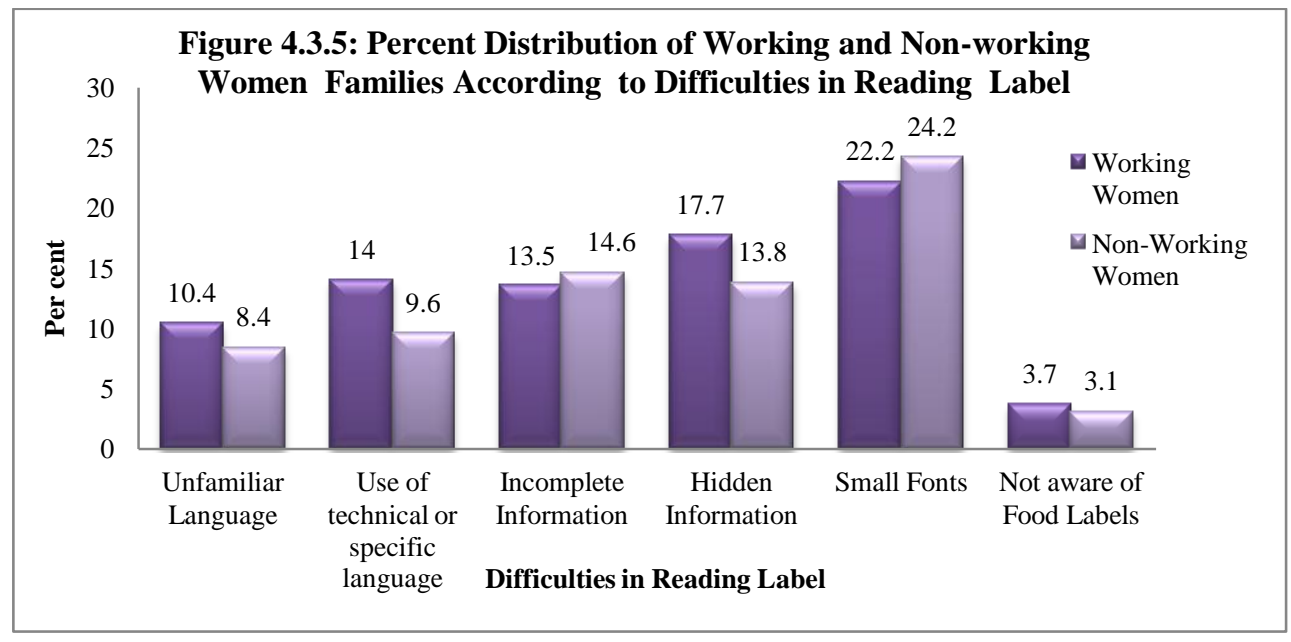

The Table 4.3.5 and Figure 4.3.5indicatethatsmall fonts (and hence difficulty in reading) was the major difficulty faced by both working $(22.2 \%)$ and non-working $(24.2 \%)$ women. It was also found that very few working $(3.7 \%)$ and non-working $(3.1 \%)$ women were unaware of food labels. Low propensity to read and use nutritional labels is due to the way consumers perceive it. Most of respondents view these labels as too scientific and difficult to understand, complaining that the letters of the nutritional table are too small and scarcely visible and that the actual nutritional values related to a single serving are not easily comprehensible. It is also important to underline that a high percentage of consumers believe that nutrition claims are not very reliable [13].

\section{CONCLUSION}

There are multiple factors that affect the consumers' behaviour towards the purchasing of processed foods. The working women were significantly $(\mathrm{p}=<0.05)$ more qualified, had one-four members in their families and number of earning members more than that of non-working women. Children were the major consumers of 
processed food in working women category whereas all the family members were the consumers of processed food in families of non-working women. TV/Radio/Internet (media), overall quality of the product, special occasions/festivals were the main factor that affects purchasing of processed food in both working and nonworking women category. The majority of non-working women preferred to buy the processed food from super market whereas majority of working women preferred to buy processed food from local kirana shop. Reading food labels for health reason and expiry date were the most important factors consider before purchasing processed food in both working and non-working women. The major reason for not reading food labels were the trust of the buyers on the brand/outlet and small font for both working and non-working women.

\section{REFERENCES}

[1] https://www.pwc.in/ winning-consumer-trust, 2015, 1-28, accessed on 24.12.15.

[2] I.Kaur, S.Sing, Consumer Behaviour of Purchase of Processed Cereal Food Products in Punjab, IOSR Journal of Business and Management, 16(2), 2014, 47-57.

[3] V. Bhaskar, N. Sundaram, Indian Consumer Purchasing Behaviour towards Branded Processed Food, Asian Social Science; 10(11),2014, 113-122.

[4] Shivkumar, Buying behaviour of consumers towards the products produced by SSI units, Indian Journal of Marketing, 34 (3),2004, 19-25.

[5] G.V. Bhawani Prasad, K. Seethakumari, Impact of advertising on consumer durable market. Indian. J. Market, 18, 1987, 21-28.

[6] D.V.Raju, Saravanan, A Study on consumer behaviour in the marketing of a household appliance in Chennai city of Tamilnadu state, Indian.J.Market. 31(3), 2001, 33-34.

[7] T.R. Rodge, Influence of advertisement on consumer of different age groups and areas. J. Market, 31(4), 2001, 10-15.

[8] B. Nagaraja, "Consumer behaviour in rural areas: A micro level study on consumer behaviour in Kavimandal", International Journal of Marketing, 34, 2004, 30-36.

[9] H.P Singh, R.C. Singhal, Packaging of processed foods under Agmark. Indian J. agric. market, 22(2): 1986, 15-17.

[10] S.Kumar, A study of the consumer behaviour with reference to selected products, Finance India, 17(4), 2003, 1478-1483.

[11] M. Bazhan, M. Mirghotbi, Z. Amiri, Food labels: An analysis of the consumers' reasons for non-use, Journal of Paramedical Sciences,6(1), 2015, 2-10.

[12] Food Safety (2009), Authority of Ireland, A Research Study into Consumers' Attitudes to Food Labellingwww.fsai.ie/WorkArea/DownloadAsset.aspx?id=8900

[13] A.Annunziata, R.Vecchio, Factors affecting use and understanding of nutrition information on food labels: evidences from consumers, Agricultural Economics Review, 13(2), 2012, 103-16.

[14] G.Pires, C.Ricardo, "Product Characteristics and Quality Perception, University at Aut'Onoma De Barcelona". http://mpra.ub.uni-muenchen.de/11142/2008 (accessed on 1 August, 2011)

[15] A Schupp, D.Reed, Consumer awareness and use of nutrition labels on packaged fresh meats. J Food Dist Res, 29(2), 1998, 24-30.

[16] B.Silverglade, Heller I.R., Food Labelling Chaos, Centre for Science in the Public Interest, Washington, DC, 2010, www.cspinet.org

[17] http://www.nhs.uk/livewell/goodfood/pages/what-are-processed-foods.aspx, Accessed on 17 July 2016. 